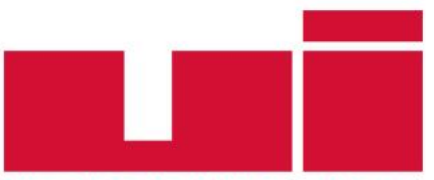

ULUSLARARASIILIȘKiLER

Akademik Dergi

Yayın ilkeleri, izinler ve abonelik hakkında ayrıntılı bilgi:

E-mail: bilgi@uidergisi.com.tr

Web: www.uidergisi.com.tr

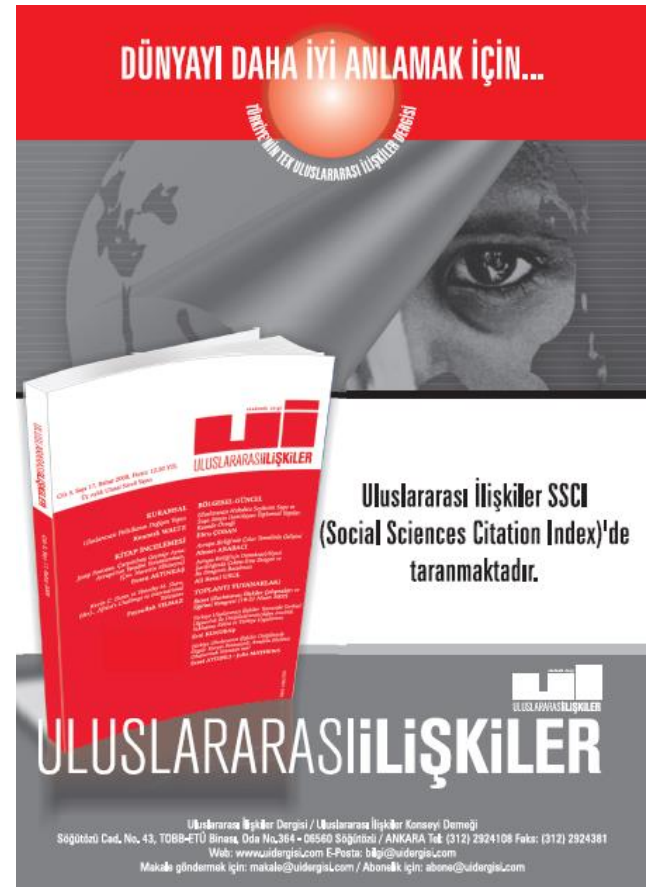

\title{
Türkiye'nin Kuzey Irak Politikasında Değişim: Turgut Özal ve Tayyip Erdoğan Dönemleri Karşılaştırmalı Analizi
}

\section{Özlem KAYHAN PUSANE**}

* Yrd. Doç. Dr., Uluslararası İlişkiler Bölümü, Işık Üniversitesi

Bu makaleye atıf icin: Kayhan Pusane, Özlem, “Türkiye'nin Kuzey Irak Politikasında Değişim: Turgut Özal ve Tayyip Erdoğan Dönemleri Karşılaştırmalı Analizi”, Uluslararası İlişkiler, Cilt 14, Sayı 56, 2017, s. 39-53.

Bu makalenin tüm hakları Uluslararası İlişkiler Konseyi Derneği'ne aittir. Önceden yazılı izin alınmadan hiç bir iletişim, kopyalama ya da yayın sistemi kullanılarak yeniden yayımlanamaz, çoğaltılamaz, dağıtılamaz, satılamaz veya herhangi bir şekilde kamunun ücretli/ücretsiz kullanımına sunulamaz. Akademik ve haber amaçlı kısa alıntılar bu kuralın dışındadır.

Aksi belirtilmediği sürece Uluslararası Illişkiler'de yayınlanan yazılarda belirtilen fikirler yalnızca yazarına/yazarlarına aittir. UİK Derneğini, editörleri ve diğer yazarları bağlamaz. 


\title{
Türkiye’nin Kuzey Irak Politikasında Değişim: Turgut Özal ve Tayyip Erdoğan Dönemleri Karşılaştırmalı Analizi
}

\author{
Özlem KAYHAN PUSANE \\ Yrd. Doç. Dr., Uluslararası İlişkiler Bölümü, İIBF, Işı Üniversitesi, İstanbul. E-posta: ozlem.pusane@isikun.edu.tr.
}

Bu araştırma TÜBİTAK 3501 Ulusal Genç Araştırmacı Kariyer Geliştirme Programı tarafindan desteklenmiştir (proje no: 114 K354).

\section{ÖZET}

1960'lardan itibaren Türk politika yapıcıları Irak'taki Kürt hareketine karşı mesafeli bir tutum takınmış ve benzer olayların Türkiye'de de yaşanmasından kaygı duymuşlardır. Fakat, Türkiye, öncelikle 1990'ların başında, sonra da 2007/2008 yıllarından itibaren, Kuzey Irak’a karşı mesafeli tutumunu bir tarafa bırakarak, aktif ve Iraklı Kürtlerle yakın ilişkiler geliştirme odaklı politikalar izlemiştir. Bu çalışmada, söz konusu iki dönemde Türkiye'nin Kuzey Irak politikası değişikliklerinin ne kadar lider kaynaklı olduğu ve ne ölçüde yapısal/çevresel unsurların etkisiyle gerçekleştiği sorularına yanıt aranmaktadır.

Anahtar Kelimeler: Türk Dış Politikası, Dış Politikada Değişim, Kuzey Irak, Tayyip Erdoğan, Turgut Özal

\section{Change in Turkey's Northern Iraq Policy: A Comparative Analysis of Turgut Özal and Tayyip Erdoğan's Tenures}

\begin{abstract}
Since the 1960s, Turkish policymakers have developed a distant attitude towards the Kurdish movement in Iraq and they have been concerned about the possibility of similar developments taking place in Turkey. However, in the early 1990s, and then from 2007/2008 onwards, Turkey left its distant attitude towards northern Iraq and pursued an active policy developing close relations with the Iraqi Kurds. This paper explores to what extent Turkey's foreign policy change towards northern Iraq in these two periods constituted leader-driven change and to what extent these changes resulted from structural/environmental factors.
\end{abstract}

Keywords: Turkish Foreign Policy, Foreign Policy Change, Northern Iraq, Tayyip Erdoğan, Turgut Özal 
1960'lardan itibaren Türkiye'nin Irak’a yönelik başlıca ilgi alanı Kürt etnik uyanışı olmuş, Türk karar alıcıları benzer olayların kendi sınırları içerisinde de gerçekleşmesinden kaygı duymuşlardır. $\mathrm{Bu}$ nedenle, Türk politika yapıcıları Irak'taki Kürt hareketine karşı mesafeli bir tutum takınmış, Kürt ayaklanmaları karşısında Irak merkezi hükümeti ile işbirliğine girişmiştir. Hatta 1983’te, PKK’nın 1984 Eruh ve Şemdinli saldırılarından bile önce, Türkiye Kuzey Irak’a ilk sınır ötesi operasyonunu gerçekleştirmiştir. $^{1}$

Türkiye’nin Kuzey Irak’a yönelik bu politikasının değiştiği iki ana dönem bulunmaktadır. Türkiye, öncelikle 1990’ların başında, sonra da 2007/2008 yıllarından itibaren, Kuzey Irak’a karşı mesafeli tutumunu bırakarak, aktif ve Iraklı Kürt liderlerle yakın ilişkiler geliştirme odaklı politikalar izlemiştir. Bu çalışma, Türkiye'nin Özal ve Erdoğan dönemlerinde yaşadığı bu değişim süreçlerini incelemeyi ve Kuzey Irak’a yönelik politika değişikliklerinin başlıca nedenleri ile değişim süreçlerinin dinamiklerini ortaya koymayı amaçlamaktadır. Yazının çıkış noktası, liderin, söz konusu dış politika değişikliği süreçlerinde, çeşitli yapısal/çevresel unsurlarla karşılaştırıldığında, nasıl bir rolünün olduğudur. Her iki dönemde de karar verme mekanizmalarında etkin liderlerin varlığı söz konusudur. Bu nedenle, Türkiye’nin Kuzey Irak’a yönelik politika değişikliklerinin ne kadar lider kaynaklı olduğu ve ne ölçüde yapısal/çevresel unsurların etkisiyle gerçekleştiği sorusu önemlidir. Bu soru yanıtlanırken iki dönemin benzerlikleri ve farklılıkları da tartışılacaktır. Dış politikada değişim literatüründe, liderlerin değişim süreçlerindeki rolüne şimdiye kadar yeterince önem verilmemiştir. Bu çalışma, Türkiye'nin Kuzey Irak’a yönelik dış politika değişim süreçlerinde liderlerin rolünü kuramsal ve sistematik şekilde ortaya koyarak literatüre katkıda bulunmayı amaçlamaktadır.

\section{Dış Politikada Değişim Üzerine Çalışmalar}

Dış politika analizi (DPA) üzerine çalışmalar 1950'lerde ortaya çıkmaya başlamışsa da, değişim konusu uzun süre ihmal edilmiştir. Bunun nedenlerinden biri, DPA çalışmalarının görece genç bir alan olması ve erken dönem araştırmaların devletlerin süreklilik gösteren davranışları üzerinde durmasıdır. ${ }^{2}$ Soğuk Savaş boyunca dış politika çalışmalarının daha çok büyük güçlerin ani değişimlerden uzak politikalarına odaklanması da dış politikada değişim konusunun göz ardı edilmesine yol açmışıı. ${ }^{3}$ Bununla birlikte, 1970’lerden itibaren Vietnam Savaşı ve Soğuk Savaş'ta yumuşama (détente) gibi uluslararası değişimler sonucu, dış politikada değişim olgusu araştırmaların merkezine oturmaya başlamıştır. Soğuk Savaş'ın sona ermesiyle birlikte konu daha fazla ilgi çekmeye başlamış, çalışmalar çeşitlenmiştir.

Zamanla dış politikada değişim üzerine kapsamlı bir uluslararası literatür ortaya çıkarken, Türkiye'deki araştırmaların aynı hızda ilerlediği söylenemez. Aslında Türk dış politikasının geçirdiği değişimlerle birlikte (NATO’ya üyelik, Orta Doğu ülkeleriyle yakınlaşma, vb.) bu konuda çeşitli çalışmalar yapılmıştır. ${ }^{4}$ Özellikle 2002'den itibaren Adalet ve Kalkınma Partisi (AKP) hükümetleri

1 Abdullah Kıran, “Türkiye’nin Kuzey Irak Politikası”, Birikim, No.148, 2001, http://www.birikimdergisi.com/birikimyazi/2907/turkiye-nin-kuzey-irak-politikasi\#_ftnref11 (Erişim Tarihi 10 Ekim 2017).

2 Jerel A. Rosati et al., "The Study of Change in Foreign Policy”, Jerel A. Rosati et al. (der.), Foreign Policy Restructuring: How Governments Respond to Global Change, Columbia, University of South Carolina, 1994, s.5.

3 Robert Gilpin, War and Change in World Politics, New York, Cambridge University Press, 1981, s.5.

4 Oral Sander, "Turkish Foreign Policy: Forces of Continuity and Change”, Ahmet Evin (der.), Modern Turkey: Continuity and Change, Opladen, VS Verlag für Sozialwissenschaften, 1984, s.115-130; Sabri Sayarı, "Turkish Foreign Policy in the PostCold War Era: The Challenges of Multi-Regionalism”, Journal of International Affairs, Cilt 54, No.1, 2000, s.169-182. 
döneminde, Türk dış politikasında yaşanan değişikliklere bağlı olarak söz konusu çalışmalar artmıştır.

Günümüzde dış politikada değişim süreçlerine ilgi artmışsa da, bu süreçlerde liderlerin rolü büyük oranda ihmal edilmiştir. Aslında liderlerin dış politikaya katkısı üzerine çeşitli çalışmalar bulunmaktadır. 1950’lerden günümüze bireylerin kişilik özellikleri, algıları, kullandıkları benzetmeler ve operasyonel kodları gibi çeşitli yönlerinin dış politika üzerindeki etkileri farklı açılardan değerlendirilmiştir. ${ }^{6}$ Fakat bu unsurların dış politikada değişimin gerçekleşmesine katkıları üzerinde pek durulmamıştır.

Literatürde liderlerin değişim süreçlerindeki rolü üzerine üç farklı bakış açısı bulunmaktadır. Bunlardan birincisi, dış politikada değişimi yalnızca yapısal/çevresel etkenlerle açıklayan çalışmalar; ${ }^{7}$ ikincisi, liderleri değişime neden olabilecek etkenlerden yalnızca biri olarak gören çalışmalar; ${ }^{8}$ üçüncüsü de ulusal ve uluslararası değişkenlerin ancak liderler aracılığıyla dış politikada değişikliğe yol açabileceğini öne süren çalışmalardır. ${ }^{9}$ Doeser ise diş politikada değişim literatürünün şimdiye kadar bireysel karar alıcıyı göz ardı ettiğini ve dış politikadaki değişikliklerin doğrudan lider kaynaklı da olabileceğini göstermiştir. ${ }^{10}$

Türkiye'nin dış politikasıyla ilgili tartışmalarda da liderlerin öneminden sıklıkla söz edilir. Özellikle son yıllarda bu alana kuramsal katkılar artmaktadır. ${ }^{11}$ Fakat, Türkiye'nin yönetici bireylerinin dış politika değişim süreçlerinin başlamasına, sürdürülmesine ve sonuçlanmasına etkilerini kuramsal ve sistematik olarak ortaya koyan çalışmalar konusunda literatür halen zayıftır. Türkiye'nin Kuzey Irak politikası değişim süreçleriyle ilgili de durum büyük oranda böyledir.

1990’lardan itibaren Türkiye’nin Kuzey Irak politikası üzerine pek çok çalışma yapılmıştır. Bu çalışmalar gerek Turgut Özal döneminde, gerekse de 2007/2008’den itibaren Tayyip Erdoğan liderliğinde Iraklı Kürtlere yönelik gerçekleşen dış politika değişikliklerini ele almışlardır. Özellikle 1991 Körfez Savaşı sonrasında Türkiye’nin Kuzey Irak politikası üzerine çalışmalar, Cumhurbaşkanı Turgut Özal'ın bu politikanın şekillenmesindeki rolünden sıklıkla söz etmiştir. ${ }^{12}$ Fakat bu

5 Kemal Kirişci, “The Transformation of Turkish Foreign Policy: The Rise of the Trading State”, New Perspectives on Turkey, No.40, 2009, s.29-56; Meliha Benli Altunışı ve Lenore G. Martin, "Making Sense of Turkish Foreign Policy in the Middle East under AKP”, Turkish Studies, Cilt 12, No.4, 2011, s.569-587.010”,rhanettin Duran, “Türk Diş naşlamıştır. ğu gibi, , e Israeli side, too. If you only want to focus on the Turkish side, you010",rhanettin Duran, “Türk Diş naşlamıştır. ğu gibi, , e Israeli side, too. If you only want to focus on the Turkish side, you010”,rhanettin Duran, “Türk Diş naşlamıştır. gu gibi, , e Israeli side, too. If you only want to focus on the Turkish side, you

6 Margaret G. Hermann, "Explaining Foreign Policy Behavior Using the Personal Characteristics of Political Leaders", International Studies Quarterly, Cilt 24, No.1, 1980, s.7-46; Robert Jervis, Perception and Misperception in International Politics, Princeton, Princeton University Press, 1976; Yuen F. Khong, Analogies at War: Korean, Munich, Dien Bien Phu, and the Vietnam Decisions of 1965, Princeton, Princeton University Press, 1992; Nathan C. Leites, The Operational Code of the Politburo, New York, McGraw Hill, 1951.

7 David B. Huxsoll, Regimes, Institutions and Foreign Policy Change, Doktora Tezi, Baton Rouge, Lousiana State University, 2003.

8 Charles F. Hermann, "Changing Course: When Governments Choose to Redirect Foreign Policy", International Studies Quarterly, Cilt 34, No.1, 1990, s.3-22.

9 Jakop Gustavsson, "How Should We Study Foreign Policy Change?", Cooperation and Conflict, Cilt 34, No.1, 1999, s.73-95.

10 Fredrik Doeser, "Leader-Driven Foreign-Policy Change: Denmark and the Persian Gulf War”, International Political Science Review, Cilt 34, No.5, 2013, s.582-597.

11 Barış Kesgin, "Leadership Traits of Turkey's Islamist and Secular Prime Ministers”, Turkish Studies, Cilt 14, No.1, 2013, s.136-157; Esra Çuhadar, et al., "Personality or Role? Comparisons of Turkish Leaders Across Different Institutional Positions”, Political Psychology, Cilt 38, No.1, 2017, s.39-54.

12 Sabri Sayarı, "Turkey: The Changing European Security Environment and the Gulf Crisis", Middle East Journal, Cilt 46, No.1, 1992, s.9-21; Mahmut B. Aykan, “Turkey’s Policy in Northern Iraq, 1991-95”, Middle Eastern Studies, Cilt 32, No.4, 1996, s.343-366; Ramazan Gözen, Amerikan Kıskacında Dış Politika: Körfez Savaşı, Turgut Özal ve Sonrası, Ankara, Liberte Yayınları, 2000. 
çalışmaların çoğu betimsel düzeyde kalmış, tartışmalar büyük oranda kuramsal bir çerçeve içerisinde gerçekleşmemiştir. ${ }^{13}$

Benzer yorumlar 2007/2008 sonrası Kuzey Irak politikasının değişim süreciyle ilgili de yapılabilir. Bu konudaki çalışmalar daha çok betimsel düzeyde kalmış, Kuzey Irak’a yönelik dış politika değişikliğinin gerçekleşmesinde, Türkiye'nin ekonomik, özellikle de enerji ihtiyaçları, Kürt sorunu, asker-sivil ilişkileri ve Suriye krizi gibi unsurların etkileri ön plana çıkarılmıştır. ${ }^{14}$ Fakat bu çalışmalarda liderin söz konusu değişim sürecindeki yeriyle ilgili dış politikada değişim kuramları bağlamında sistematik bir tartışma bulunmamaktadır.

Gerek 1990’ların başında Turgut Özal, gerekse 2007/2008 yıllarından sonra Tayyip Erdoğan liderliğinde Türk dış politikasında Kuzey Irak’a yönelik gerçekleşen değişime karşılaştırmalı bir bakış açısı sağlayan çalışmalar da yok denecek kadar azdır. Bazı araştırmacılar iki dönem arasındaki farklılıklardan söz etmişlerdir. ${ }^{15}$ Bu konudan bağımsız olarak Özal ve Erdoğan'ı çeşitli liderlik özellikleri açısından karşılaştıran çalışmalar da yapılmıştır. ${ }^{16}$ Fakat Türkiye'nin Kuzey Irak’a yönelik tecrübe ettiği dış politika değişim süreçlerinin sistematik şekilde, karşılaştırmalı olarak ele alındığı ve bu süreçlerde liderlerin rollerinin de kuramsal bağlamda tartışıldığı bir çalışma literatürde bulunmamaktadır.

\section{Turgut Özal Döneminde Türkiye'nin Kuzey Irak Politikasında Yaşanan Değişiklik}

Türkiye’nin Kuzey Irak’a yönelik dış politikasındaki değişim, esas olarak 1991 Körfez Savaşı́nın son evresinde ortaya çıkmıştır. Irak'ın Kuveyt'i 1990 yazında işgal etmesinden sonra, Amerika Birleşik Devletleri (ABD) liderliğinde ve Birleşmiş Milletler (BM) çerçevesinde oluşturulan uluslararası koalisyon, Irak güçlerinin Kuveyt'ten çekilmesini sağlamak amacıyla, önce Irak’a karşı hava harekâtı, sonra sınırlı bir kara harekâtı gerçekleştirmiştir. Bu uluslararası baskı, Saddam Hüseyin’i Kuveyt’ten çekilmeye mecbur bıraksa da, harekâtların sonunda Irak'ın kuzeyinde ve güneyinde ayaklanmalar çıkmıştır. Kuzey Irak'ta başlayan ayaklanma, 500,000 kadar Iraklı Kürt'ün Türkiye-Irak sınırına yığılmasına neden olmuştur. Bu durum, Türk politika yapıcılarında ciddi endişelere yol açmıştır. Çünkü insani açıdan, Iraklı Kürtleri Türkiye sınırları dışında tutmak zor olmakla birlikte, binlerce Iraklı Kürt'ün Türkiye'ye girişi de Kürt sorunu açısından olumsuz sonuçlar doğurabilecek bir durumdur. Bu endişeler sonucunda Turgut Özal Türkiye-Irak sınırında güvenli bir bölgenin kurulması çağrısında bulunmuş ve bu çağr ile başlayan süreç, 36. paralelin kuzeyinde uçuşa yasak bir bölgenin (no-fly zone) ve buna bağlı olarak Kuzey Irak’ta Kürtleri Saddam Hüseyin rejiminden koruma amaçlı bir güvenli

13 Bir istisna olarak bkz. Gözen, Amerikan Kıskacında Dış Politika.

14 Henri J. Barkey, On the KRG, the Turkish-Kurdish Peace Process, and the Future of the Kurds, Global Turkey in Europe Series Working Paper 12, 24 Temmuz 2015; Marianna Charountaki, “Turkish Foreign Policy and the Kurdistan Regional Government”, Perceptions, Cilt 17, No.4, 2012, s.185-208; Gönül Tol, "Untangling the Turkey-KRG Energy Partnership: Looking Beyond Economic Drivers”, Global Turkey in Europe Series Policy Brief, No.14, 26 Mart 2014.

15 Meliha Benli Altunışı,, "Worldviews and Turkish Foreign Policy in the Middle East", New Perspectives on Turkey, No.40, 2009, s.169-192; Charountaki, “Turkish Foreign Policy and the Kurdistan Regional Government”.

16 Metin Heper, "Islam, Conservatism, and Democracy in Turkey: Comparing Turgut Özal and Recep Tayyip Erdoğan”, Insight Turkey, Cilt 15, No.2, 2013, s.141-156; Ömer Ak, "Liderlik Profili Analizi ve Dış Politika: Turgut Özal ve Recep Tayyip Erdoğan”, Ertan Efegil ve Rıdvan Kalaycı (der.), Dıs, Politika Teorileri Baglamında Türk Dıs, Politikasının Analizi, Cilt 1, Ankara, Nobel Yayınevi, 2012, s.501-527; Çuhadar, et al., "Personality or Role?”. 
alanın (safe haven) oluşturulmasına yol açmıştır. Özal, Türkiye’nin Iraklı Kürt liderlerle ilişkilerini geliştirmek için de büyük çaba harcamıştır.

1990’ların başında Türkiye’nin Kuzey Irak politikasıyla ilgili tartışmalar, çoğunlukla Turgut Özal'ı temel aktör olarak tanımlamıştır. Fakat bu değişim süreci, Özal'ın süreçteki önemli rolüne rağmen Hermann ve Doeser'in çalışmalarında ${ }^{17}$ tartıştıkları lider-kaynaklı değişimin bir örneği olarak değerlendirilebilir mi? Hermann ve Doeser'e göre lider-kaynaklı değişim, başlıca politika yapıcının, vizyonu açısından gerekli gördüğü dış politika değişikliklerini gerçekleştirmesi sonucu ortaya çıkar. Buna göre, çeşitli çevresel/yapısal unsurlar bir konuyu gündeme getirip değişimi gerekli kılmadan önce bile lider ilgili konuda değişim arzusuna sahiptir. Yapısal/çevresel unsurlar, liderin gerçekleştirmek istediği dış politika değişimi için yalnızca bir fursat penceresi (window of opportunity) görevi görür. Bununla birlikte, liderin dış politika değişikliğiyle ilgili siyasi risk almaya hazırlıklı olması ile kendisinden farklı görüşteki aktörleri ikna etmek için gerekli beceri ve deneyime sahip olması, lider-kaynaklı değişimi kolaylaştırır. ${ }^{18}$

1983'ten itibaren Turgut Özal'ın konuşmaları, mülakatları, basın toplantıları ile Anavatan Partisi (ANAP) seçim beyannameleri incelendiğinde, Kuzey Irak kavramının 1991 Körfez Savaşı́na kadar Özal'ın dış politika söyleminin merkezinde bir kavram olmadığı gözlemlenebilir. 1980'lerin ortalarına kadar Özal'ın daha çok Türkiye'nin Orta Doğu ve İslam dünyasına bakışı üzerine değerlendirmeler yaptığı görülmekte, Irak konusu, İran-Irak savaşı çerçevesinde gündeme gelmektedir. Bununla birlikte, Turgut Özal'ın 1983'te başbakan olarak göreve başladığında sahip olduğu dış politika söylemi, Türkiye'nin 1990’ların başındaki Kuzey Irak’a yönelik politika değişikliğinin de kökeninde bulunmaktadır.

Özal'ın dış politika söyleminin iki temel unsuru vardır: Birincisi, ekonomi üzerine odaklanmaktır. Özal'ın başbakanlık dönemi, ciddi bir ekonomik kriz sonrasında başlamıştır. Bu nedenle, dış politika söylemi önemli ölçüde, ülkenin ekonomik kalkınması, özellikle de ihracatı arttırma üzerine eğilmiştir. İkinci unsur, Özal’ın, Türkiye'nin aktif bir dış politika izlemesi gerektiği inancıdır. Özal'ın bu görüşünü başbakan olmadan önceki açıklamalarında bile görmek mümkündür. 1983 seçimlerinden önce Turgut Özal, ANAP'ın hükümeti kurduktan sonra aktif bir dış politikayla Türkiye'nin uluslararası saygınlığını arttıracağını belirtmiştir. ${ }^{19}$ Bu söylem, Türkiye'nin hem Batı, hem de Orta Doğu ile ilişkilerini geliştirmeye yönelik bir çabanın işaretini vermiştir. Özal'a göre Türkiye Doğu ve Batı arasında bir köprü olarak her iki bölgeye ait olmanın da avantajlarından yararlanmalıdır. ${ }^{20}$ Gerçekten de 1983 seçim beyannamesinde ANAP sadece Türkiye'nin Batı dünyasıyla ilişkilerinde değil, Orta Doğu ve diğer İslam ülkelerine yönelik dış politikasında da aktif bir yaklaşımın sözünü vermiştir. Tablo 1'de de vurgulandığı üzere 1991 Körfez Krizi’ne kadar Turgut Özal'ın hem dış politika söylemi, hem de attığı adımlar Türkiye'nin bir yandan Batı ile ilişkilerini öne çıkarırken, diğer yandan Orta Doğu ve İslam ülkeleriyle siyasi ve ekonomik bağlarını güçlendirmenin önemi üzerinde durmuştur.

17 Hermann, "Changing Course"; Doeser, "Leader-Driven Foreign-Policy Change”.

18 Doeser, "Leader-Driven Foreign-Policy Change”, s.4-5.

19 “Özal: İktidara Geldiğimizde Dışarıda Türkiye'nin İtibarını Artıracağız”, Milliyet, 6 Eylül 1983, s.9.

20 Gözen, Amerikan Kıskacında Dış Politika, s.132. 
Tablo 1 Turgut Özal'ın Dış Politika Söylemi

\begin{tabular}{|l|l|l|}
\hline \multicolumn{1}{|c|}{ Orta Doğu ve Irak } & \multicolumn{1}{|c|}{\begin{tabular}{c}
\multicolumn{1}{c|}{ Kuzey Irak } \\
(Körfez Savaşı ve hemen sonrası dönem)
\end{tabular}} \\
\hline Söylem & $\begin{array}{l}\text { Batı ve Doğu arasında köprü olarak Türkiye; Orta } \\
\text { Doğu ve İslam ülkeleriyle kardeşlik bağı; coğrafi, } \\
\text { tarihi, kültürel bağlantılar; Orta Doğunun karışık } \\
\text { siyasi ortamında istikrar adası olarak Türkiye }\end{array}$ & $\begin{array}{l}\text { BM kararları ve uluslararası koalisyonla hareket } \\
\text { eden Türkiye; Iraklı Kürtlerle asırlar süren birlikte } \\
\text { yaşam; akrabalık bağı; Türkiye üzerinde yük } \\
\text { oluşturabilecek, güvenlik kaygısı yaratabilecek } \\
\text { Iraklı Kürt sığınmacılar }\end{array}$ \\
\hline Dış politika & $\begin{array}{l}\text { Orta Doğu: Aktif dış politika; Batı ile sıkı bağlar, } \\
\text { bölge ülkeleriyle ekonomik ilişkiler; bölgede } \\
\text { taraf olmaktan kaçınma ve istikrarın kurulmasına } \\
\text { yardımcı olacak çabalar } \\
\text { Irak: Artan ticari ilişkiler, PKK’ya karşı işbirliği }\end{array}$ & $\begin{array}{l}\text { Aktif dış politika; Iraklı Kürt sığınmacıların } \\
\text { ülkelerine dönmelerini sağlamak amacıyla güvenli } \\
\text { bölge oluşturma; bağımsız bir Kürt devleti } \\
\text { olasılı̆ına karşı muhalefet; Iraklı Kürtlerle iyi } \\
\text { ilişkiler geliştirme }\end{array}$ \\
\hline
\end{tabular}

Türkiye'nin 1990'ların başındaki Kuzey Irak politikası da Turgut Özal'ın Türkiye'yi Batı ile Doğu'nun merkezinde konumlandıran aktif dış politika anlayışının bir parçasıdır. Körfez Savaşı boyunca Özal, Türkiye'nin BM kararları çerçevesinde ve uluslararası koalisyonla birlikte hareket etmesi gerektiğine inanmıştır. Bununla birlikte, Iraklı Kürtlerle komşuluk ve akrabalık bağlarından hareketle Türkiye'nin Irak'tan algıladığı tehditlere karşı önlemler alınmasında aktif rol oynamıştır.

1990'ların başında Türkiye’nin Kuzey Irak politikasında yaşadığı değişim sürecinin başlatılmasında ve sonuçlanmasında Turgut Özal başlıca aktör olarak karşımıza çıkmaktadır. Bu nedenle söz konusu dış politika değişikliği kısmen de olsa Hermann ve Doeser’ in gündeme getirdikleri lider-kaynaklı değişimin bir örneği olarak değerlendirilebilir. Fakat bu kavram, Türkiye'nin Kuzey Irak’a yönelik dış politikasında meydana gelen değişikliği tam olarak açıklayamamaktadır. Her ne kadar Özal'ın aktif dış politika anlayışı söz konusu değişikliğin temelini oluştursa da, Soğuk Savaş’ın sona ermesini ve 1991 Körfez Savaşı́nın ortaya çıkardığı bölgesel koşulları hesaba katmadan Kuzey Irak politikasının ayrıntılarını anlamak mümkün değildir. Öyleyse bu dış politika değişim sürecini her yönüyle açıklayabilmek için Jakob Gustavsson'ın geliştirdiği kapsamlı kuramsal çerçeveye de başvurmak yararlı olacaktır.

Gustavsson’a göre, dış politika değişim süreçleriyle ilgili tam bir kavrayışa sahip olabilmek için temel yapısal koşullardaki değişikliklere, stratejik siyasi liderliğe ve bir kriz durumunun var olup olmadığına aynı anda bakmak gereklidir. ${ }^{21}$ Gustavsson, dış politika değişikliklerinin üç aşamada açıklanabileceğini söyler. İlk aşama değişimin kaynağıdır. Değişimin kaynağı, çeşitli yurt içi, yurt dışı, siyasi ya da ekonomik unsurları içeren temel yapısal koşullara işaret eder. İkinci aşama bireysel algılarla ilgilidir. Burada Gustavsson, yapısal unsurların ancak bireysel karar alıcıların bu unsurları algılayıp onlara karşılık vermesi sonucu dış politikada değişime neden olabileceğini söylemek istemiştir. Son aşama, karar alma aşamasıdır. Bu durum, politika yapıcının dış politikada değişikliğin gerekliliğine inanması durumunda, değişimi hayata geçirebilmek amacıyla, var olan kurumsal ve siyasal mekanizmalar çerçevesinde çalışması anlamına gelir. ${ }^{22} \mathrm{Bu}$ üç aşamalı süreç içerisinde Gustavsson kriz durumlarının önemini vurgulamıştır. Bir kriz durumunun varlı̆̆ı, sürece aciliyet getireceğinden, dış politika değişikliğini daha olası kılar. Krizler, politika yapıcının yerleşik çıkarları ve kurumsal ataleti zayıflatmasını daha olanaklı hale getirmesi açısından önemlidir. ${ }^{23}$

21 Gustavsson, "How Should We Study Foreign Policy Change?", s.74.

22 Ibid., s.83-85.

23 Ibid., s.86 
Gustavsson'un geliştirdiği model, Türkiye’nin 1990’ların başında Kuzey Irak’a yönelik gerçekleştirdiği dış politika değişikliğinin ayrıntılarını açıklamakta bizlere yararlı bir analitik çerçeve sunmaktadır. Öncelikle, Soğuk Savaş’ın sona ermesi, Türkiye’nin bu dönemde yaşadığı çok temel yapısal bir değişimdir. Soğuk Savaş’ın bitişi, NATO'nun geleceği ve Türkiye'nin Avrupa güvenlik politikalarındaki yeri üzerine önemli sorular ortaya çıarmıştır. ${ }^{24} \mathrm{Bu}$ durum, Türk politika yapıcılarında ciddi endişelere yol açmış, Turgut Özal Sovyet tehdidinin ortadan kalkmasıyla birlikte Türkiye'nin Batı ittifakındaki önemini kaybettiği iddialarından rahatsızlık duymuştur. ${ }^{25}$

Bu dönemde Türkiye'nin karşısına çıkan diğer bir uluslararası gelişme, Ağustos 1990'da Irak'ın Kuveyt'i işgalidir. Aslında Türkiye ve Irak uzun yıllar iyi ilişkiler sürdürmüşlerdir. Fakat 1980'lerde Türk politika yapıcılar, Irak'ın nükleer ve kimyasal silah programlarını da içeren askeri yığınağından rahatsızlık duymaya başlamışlardır. Bu dönemde Fırat Nehri üzerinde kurulan Atatürk Barajı, Irak'ın su kaynaklarının azalmasına yol açtığından, Türkiye ve Irak arasındaki gerilimi arttırmıştır. ${ }^{26}$

Irak'ın Kuveyt'i işgali, Türkiye'nin Irak'la ilgili tehdit algısını güçlendirmiştir. Bu gelişme, Türk politika yapıcıları arasında, bölgedeki güç dengesinin değiştiği düşüncesinin güçlenmesine neden olmuştur. Türk politika yapıcıları Körfez Savaşı sonrasında Irak'ın geleceğiyle ilgili de ciddi endişe duymuşlardır. Turgut Özal, Saddam Hüseyin'in savaşın sonrasında iktidarda kalamayacağını düşünmüş, Irak'ın bölünebileceğinden ve bunun bağımsız bir Kürt devletinin kurulmasına yol açabileceğinden endişe etmiştir. ${ }^{27}$

Hem Türkiye'nin Batı ittifakı içerisindeki öneminin azaldığına, hem de Irak'ta bağımsız bir Kürt devleti kurulabileceğine dair endişeler nedeniyle Turgut Özal, Türkiye’nin, Saddam Hüseyin'in askeri güçlerinin Kuveyt'ten çıkarılmasına yönelik uluslararası çabalar içerisinde aktif bir rol almasını gerekli görmüştür. Özal aktif bir dış politikayla bir yandan Türkiye’nin Batı için hala önemli bir stratejik müttefik olduğunu göstermek istemiş, diğer yandan da bu şekilde Irak’n bölünmesi durumunda Türkiye'nin bölgedeki gelişmelerde söz sahibi olabileceğini düşünmüştür. Turgut Özal, aslında 1980’lerin başından itibaren Türkiye için aktif bir dış politikayı desteklemiştir. Fakat Soğuk Savaş'ın sona ermesi ve Kuveyt'in işgali, Özal'ın bu düşüncesi için yeni bir itici güç olmuştur.

Türkiye'nin Kuzey Irak politikası açısından Gustavsson'un vurguladığı kriz durumu ise 1991 Körfez Savaşı'nın son evrelerinde yaşanmıştır. Bu dönemde Irak'ın kuzey ve güneyinde ayaklanmalar çıkmış, özellikle Saddam Hüseyin'in Irak'ın kuzeyindeki ayaklanmayı bastırma politikası sonucunda yüzbinlerce Iraklı Kürt Nisan 1991'e kadar Türkiye sınırına yığılmıştır.

Gustavsson'un modeli uyarınca bu kriz temel karar alıcı Turgut Özal tarafından algılanmış ve Türkiye'nin politikası önemli oranda Özal'ın tercihleri doğrultusunda şekillenmiştir. Bu süreçte Özal'ın önceliği, Iraklı Kürtlerin bir an önce ülkelerine dönebilmeleri ve Türkiye'nin Kuzey Irak'ın geleceğiyle ilgili gelişmelerde söz sahibi olmasını sağlamak olmuştur.

Turgut Özal, 1980’lerden beri geliştirdiği aktif dış politika söylemi çerçevesinde öncelikle 688 sayılı BM Güvenlik Kurulu kararının ortaya çıkmasında önemli bir rol oynamıştır. Bu karar Iraklı sivillerin, özellikle de Kürtlerin, baskı altında tutulmasını kınamış ve Iraklı Kürtlerin ihtiyaçlarının

24 Sayarı, “Turkey”, s.10.

25 Gözen, Amerikan Kıskacında Dış Politika, s.135.

26 Sayarı, “Turkey”, s.13.

27 Mahmut B. Aykan, Türkiyénin Kuveyt Krizi (1990-91) Politikası: 1998 Yilından Geriye Yönelik Bir Yeniden Değerlendirme, Ankara, Dış Politika Enstitüsü, 1998, s.50; Cengiz Çandar, “Turgut Özal Twenty Years After: The Man and the Politician”, Insight Turkey, Cilt 15, No.2, 2013, s.32. 
aciliyetle irdelenmesi gerektiğini belirtmiştir. BM’nin, Iraklı Kürtlerin içinde bulunduğu zor durumu tanıması sonucu Özal, Kuzey Irak’ta Kürtler için güvenli bir bölgenin oluşturulmasında büyük çaba göstermiştir.

1990’ların başlarında Türkiye'nin Kuzey Irak politikasında gerçekleşen bir diğer değişiklik, Turgut Özal'ın Iraklı Kürt liderlerle yakın ilişki kurma çabalarıdır. Özal'ın amacı, Kuzey Irak'taki gelişmelerle ilgili birinci elden bilgi alabilmek ve Iraklı Kürtlerin geleceğinde söz sahibi olabilmektir. ${ }^{28}$ Bu politikanın bir parçası olarak Celal Talabani ile Mesut Barzani'nin bir temsilcisi Mart 1991'de gizlice Ankara'ya davet edilmiştir. Turgut Özal bu dönemde Iraklı Kürt liderlerle PKK’ya karşı bir işbirliği (bu pratik anlamda çok büyük işlerlik kazanamasa da) kurulması konusunda da önemli rol oynamıştır. Talabani ve Barzani'ye Türk diplomatik pasaportları verilmiş ve Ankara'da partilerinin temsilciliklerini açmalarına izin verilmiştir. ${ }^{29}$

Bununla birlikte, Özal için Türkiye’nin Kuzey Irak politikasında değişikliğe gitmek kolay olmamıştır. Özal, Irak'ın Kuveyt'i işgali karşısında kurulan uluslararası koalisyona Türk askeri birliklerinin katılmasını arzu etmesine rağmen Genelkurmay ve Dışişleri Bakanlığı buna karşı çıkmıştır. Bu durum Türkiye’nin Körfez Savaşı sırasında yürüttüğü aktif dış politikanın sınırlarını çizmiş, Türkiye'nin uluslararası koalisyona katılımının sınırlı düzeyde gerçekleşmesine yol açmıştır. Uçuşa yasak bölge konusunda, Dışişleri Bakanlığı ve Genelkurmay Başkanlığı’nın temel çekincesi ileride bölgede bağımsız bir Kürt devleti kurulması olasılığıdır. ${ }^{30}$ Özellikle askerin endişesi, Turgut Özal'ın Körfez Savaşı sırasında büyük oranda ABD’nin çıkarları doğrultusunda hareket ettiğine olan inancıdır. ${ }^{31}$ Fakat BM Güvenlik Konseyi'nin 688 sayılı kararı bu eleştirileri bir nebze azaltmıştır. İlgili kararla, Türkiye'nin Kuzey Irak’ta kurulan güvenli bölge ile uçuşa yasak bölge için sağladığı katkılar onun uluslararası yükümlülüğü haline gelmiştir. Türkiye'nin Iraklı Kürt liderlerle yakın ilişkiler kurma çabalarına gelince, geleneksel Türk dış politikası aktörleri, Iraklı Kürtler ile PKK arasındaki bağlantıdan endişe duymuşlar ve Türkiye’nin uzun süredir yürürlükte olan Iraklı Kürt liderlerle ilişki kurmama politikasını sürdürmek istemişlerdir. Fakat Özal büyük çabalar sonucu Dışişleri Bakanlığı bürokratlarını ve askerleri Kuzey Irak’tan birinci el bilgi almanın öneminin Türkiye'nin çıkarına olduğu konusunda ikna etmiştir. ${ }^{32}$

\section{Tayyip Erdoğan Döneminde Türkiye'nin Kuzey Irak Politikasında Yaşanan Değişiklik}

Kuzey Irak'ta zamanla genişleyen Kürt özerk yapılanması, Türk politika yapıcıları tarafından hayati bir tehdit olarak algılanmıştır. Bu çekince, 1991 Körfez Savaşı sonunda Iraklı Kürtler için Kuzey Irak'ta kurulan uçuşa yasak bölge ve buna bağlı olarak ortaya çıan güvenli bölgeyle birlikte daha da artmıştır. Söz konusu güvenli bölge PKK'nın da rahatça hareket edebildiği bir yaşam alanı haline dönüşmüştür. Aslında 1999'da PKK lideri Abdullah Öcalan’ın yakalanmasıyla birlikte PKK terörünün görece oldukça azalması sonucu Türkiye'nin Kuzey Irak'la ilgili rahatsızlığı hafiflemiştir. Fakat 2003'te

28 Özal'ın Iraklı Kürtlerle yakın ilişkiler geliştirme politikası onun Türkiye Kürtlerine bakışı ve liberal, demokratik bir devlet anlayışıyla da yakından ilişkilidir. Bkz. Muhittin Ataman, "Özal Leadership and Restructuring of Turkish Ethnic Policy in the 1980s”, Middle Eastern Studies, Cilt 38, No.4, 2002, s.123-142.

29 International Crisis Group, Turkey and the Iraqi Kurds: Conflict or Cooperation? 13 Kasim 2008, s.1.

30 Aykan, "Turkey's Policy in Northern Iraq".

31 Cengiz Çandar, "Some Turkish Perspectives on the United States and American Policy Toward Turkey", Morton Abramowitz (der.), Turkey's Transformation and American Policy, New York, The Century Foundation Press, 2000, s.137.

32 Aziz Utkan, “Kürt Liderlerle Askeri Toplantı”, Hürriyet, 12 Ağustos 1991. 
ABD'nin Irak'ı işgaliyle Kuzey Irak politika yapıcılar tarafından yeniden önemli bir tehdit olarak algılanmaya başlamıştır. ABD'nin Irak'ı işgali, TSK'nın Kuzey Irak'ta 1990'larda PKK'yla mücadele çerçevesinde kurduğu varlığı sona erdirmiş, 2005'te yürürlüğe giren Irak Anayasası da Irak Kürdistan Bölgesel Yönetimi’ne (IKBY) resmi statü kazandırmıştır.

2007/2008'den itibaren Başbakan (daha sonra Cumhurbaşkanı) Tayyip Erdoğan liderliğinde gerçekleşen Türkiye'nin Kuzey Irak politikası değişikliği de Gustavsson ve Doeser'in kuramsal modelleri çerçevesinde açıklanabilir. Çünkü söz konusu dış politika değişikliği, kavramsal olarak AKP'nin "stratejik derinlik" doktrini ve "komşularla sıfır sorun" politikasının bir uzantısı olarak görülebilir. Yani 2003 Irak Savaşı ile 2004’te PKK’nın tek taraflı ateşkesini sonlandırmasından önce bile Tayyip Erdoğan liderliğindeki hükümetin Türkiye'nin Orta Doğu politikasını değiştirme vizyonu bulunmaktadır. Ahmet Davutoğlu’nun etkisinin büyük oranda hissedildiği bu vizyona göre, Türkiye'nin bölgede düzen kurucu rolü ve proaktif bir dış politikanın önemi vurgulanmıştır. Hatta AKP’nin 2002 seçim beyannamesinde, Türkiye'nin jeopolitik konumundan doğan potansiyelin bölgesel ve küresel bir etkiye dönüştürülmesinin öneminden söz edilmiştir. ${ }^{33}$ Diğer taraftan, 2000'lerin başlarından itibaren ifade edilen komşularla sıfır sorun söylemi, Irak Savaşı'nın başlamasıyla ve PKK'nın Türkiye'ye karşı tek taraflı ateşkesini sonlandırmasıyla birlikte farklı dinamikler kazanmış ve Kuzey Irak politikasının değişimi için yeni motivasyonlar yaratmıştır. Böylelikle, Türkiye'nin 2007/2008 sonrası yaşadığı Kuzey Irak politikası değişim sürecinin de lider-kaynaklı değişim kavramının mükemmel bir örneği olduğu söylenemez.

2000'lerin başlarından itibaren Tayyip Erdoğan'ın konuşmaları, mülakatları, basın toplantıları ile AKP seçim beyannameleri incelendiğinde, Türkiye-Irak ilişkilerinin bu dönemde daha çok Irak Savaşı etrafında tartışıldığı görülür. Bu dönemde sıklıkla dile getirilen endişe, 1991 Körfez Savaşı sonrasında tecrübe edilen, PKK'nın Kuzey Irak'ta varlığının güçlenmesi ve Türkiye'ye karşı şiddet eylemlerinin artması gibi bir sonucun benzerinin, Irak Savaşı sonrasında da yaşanma olasılığıdır. Bu nedenle Başbakanlık görevine başlamadan önce bile Erdoğan, Körfez Savaşı́ndan sonra PKK'nın bölgede bir yaşam alanı kurabildiğine ve Türkiye'nin bedel ödememek için dikkatli hareket etmesi gerektiğine vurgu yapmıştır. ${ }^{34} \mathrm{Bu}$ tür gelişmelerin önüne geçebilmek için Türkiye'nin Kuzey Irak'ta etkin bir varlık göstermesinin gerekliliği de sıkça tekrarlanmıştır. Bununla birlikte, Turgut Özal'dan farklı olarak Erdoğan, 2000'lerin başlarından itibaren Türk dış politika söyleminin belirlenmesinde etkili tek aktör değildir. Davutoğlu'nun ana hatlarını çizdiği vizyon, ${ }^{35}$ Tayyip Erdoğan tarafından da benimsenmiş ve onun dış politika söyleminin temel kaynağını oluşturmuştur.

Davutoğlu'nun dış politika anlayışını şekillendiren başlıca nokta "stratejik derinlik" kavramıdır. Bu kavram, coğrafi ve tarihi derinlik olarak iki boyutta açıklanabilir. ${ }^{36}$ Coğrafi olarak, Türkiye'nin pek çok bölgesel kimliği vardır ve bu kimlik tek bir bölgeyle ilişkilendirilerek tanımlanamaz. ${ }^{37}$ Türkiye’nin tarihsel derinliğine bakıldığında ise Davutoğlu'nun dış politika vizyonunda Türkiye’nin özellikle

33 Ak Parti Seçim Beyannamesi, 2002, s. 91.

34 Serpil Çevikcan, “Bir Kere Tokat Yedik, Yalnız Kalmamalıyız, Milliyet, 18 Aralık 2002, s.16.

35 Ahmet Davutoğlu’nun 2009'da Dışişleri Bakanı olması dış politikadaki etkisini arttırmışsa da, 2002'de başlayan Başbakanlık başdanışmanlığı görevinden itibaren Türk dış politikası üzerinde etkili başlıca aktörlerden biri olduğu yaygın biçimde kabul edilmektedir. Bkz. Bülent Aras ve Aylin Görener, "National Role Conceptions and Foreign Policy Orientation: The Ideational Bases of the Justice and Development Party's Foreign Policy Activism in the Middle East", Journal of Balkan and Near Eastern Studies, Cilt 12, No.1, 2010, s.81; International Crisis Group, Turkey and the Middle East: Ambitions and Constraints, 7 April 2010.

36 Aras ve Görener, "National Role Conceptions and Foreign Policy Orientation”, s.82.

37 Ahmet Davutoğlu, “Turkey’s Foreign Policy Vision: An Assessment of 2007”, Insight Turkey, Cilt 10, No.1, 2008 , s.78. 
Osmanlı geçmişiyle bağlarını sürdürmesinin önemi vurgulanmaktadır. Bu anlayışa göre, Türkiye’nin tarihsel ve kültürel bağlarından uzaklaşması, ona politik ve ekonomik alanda önemli firsatlar kaybettirmiştir. ${ }^{38}$ Bu nedenle, stratejik derinlik doktrini, Türkiye’nin çevresindeki bölgelerle ilişkilerini geliştirme odaklı, aktif/proaktif ve katılımcı bir dış politika öngörür. ${ }^{39}$ Komşularla sıfır sorun kavramı Davutoğlu tarafından bu anlayışı vurgulamak için sıkça kullanılmıştır.

Tablo 2 Tayyip Erdoğan’ın Dış Politika Söylemi

\begin{tabular}{|l|l|l|l|}
\hline & \multicolumn{1}{|c|}{ Orta Doğu } & \multicolumn{1}{|c|}{ Kuzey Irak (2002-2008 arası) } & \multicolumn{1}{c|}{ Kuzey Irak (2008-...) } \\
\hline Söylem & $\begin{array}{l}\text { Türkiye'nin uluslararası } \\
\text { sistemin merkezinde bir ülke, } \\
\text { bölgede istikrar unsuru oluşu; } \\
\text { bölge ülkeleri ile tarihsel, } \\
\text { kültürel bağlar }\end{array}$ & $\begin{array}{l}\text { Türkiye'nin Kuzey Irak'taki PKK } \\
\text { varlığı endişesi ile bu konudaki } \\
\text { ulusal güvenlik tehdidi algılaması; } \\
\text { komşumuz olarak Irak }\end{array}$ & $\begin{array}{l}\text { Türkiye'nin, IKBY'nin politik } \\
\text { ve ekonomik ortağı oluşu; } \\
\text { Türkiye'nin akrabaları olarak } \\
\text { Iraklı Kürtler; Türkiye ve } \\
\text { IKBY'nin, PKK üzerinde ortak } \\
\text { yaklaşım geliştirmeye çalışması }\end{array}$ \\
\hline Dış politika & $\begin{array}{l}\text { Proaktif dış politika; bölgesel } \\
\text { krizlerin çözümüne katkıda } \\
\text { bulunma; komşularla sıfır } \\
\text { sorun; yumuşak güç vurgusu, } \\
\text { bölgesel ekonomik ilişkilerin } \\
\text { güçlenmesi }\end{array}$ & $\begin{array}{l}\text { Irak Savaşı öncesi Kuzey Irak'ta } \\
\text { etkin rol oynama çabaları; } \\
\text { 2007'de ABD ile anlaşma sonucu } \\
\text { Kuzey Irak'taki PKK hedeflerine } \\
\text { sinır ötesi operasyonlar; IKBY } \\
\text { ile ekonomik ilişkilerin ivme } \\
\text { kazanmaya başlaması }\end{array}$ & $\begin{array}{l}\text { IKBY ile yakın politik, ekonomik } \\
\text { ilişkiler, artan ticaret ve } \\
\text { yatırımlar, enerji anlaşmaları; } \\
\text { Mesut Barzani'nin Kürt } \\
\text { sorununun çözümüne yönelik } \\
\text { çabalarda kolaylaştırıcı rolü }\end{array}$ \\
\hline
\end{tabular}

Ahmet Davutoğlu tarafından ana hatları çizilen dış politika söylemi, Başbakan (daha sonra Cumhurbaşkanı) Tayyip Erdoğan liderliğinde uygulanma fırsatına kavuşmuştur. Türkiye’nin özellikle 2007/2008'den itibaren netleştirdiği IKBY ile ilişkilerini geliştirme politikası da, Türkiye'nin bölgesel ve küresel bir aktör konumuna gelmesinin, nüfuz alanını genişletme arzusunun, aktif/dinamik/çok yönlü bir dış politika izlemesinin ve komşularla sorunlarını çözme çabasının önemini vurgulayan söylemin kritik bir parçası olarak düşünülebilir. ${ }^{40}$

Tablo 2'de de belirtildiği gibi, 2000'lerin başlarında Tayyip Erdoğan'ın Kuzey Irak’a bakışı, daha çok Irak Savaşı ve PKK’nın buradaki varlığının güçlenmesi üzerinden şekillenmiştir. Bu dönemde her ne kadar Türkiye'nin Iraklı Kürtlerle ekonomik ilişkileri ivme kazanmaya başlasa da, temel odak noktası PKK tehdididir.

Türkiye ile Iraklı Kürtler arasındaki ilk üst düzey resmi görüşme 2008 'de gerçekleşmiştir. ${ }^{41} \mathrm{Bu}$ dönemde Tayyip Erdoğan Iraklı Kürtlerden Türklerin akrabaları olarak söz etmeye başlamıştır. ${ }^{42}$ Hatta Ekim 2008'de Erdoğan, “[a]rtık siyasetçi de, yatırımcı da, sanayici de, aydınlarımız da, medyamız da, sivil toplum kuruluşlarımız da konuyu [IKBY ile ilişkiler] sadece bir güvenlik sorunu olarak görmekten vazgeçmelidir” demiştir.

38 Aras ve Görener, "National Role Conceptions and Foreign Policy Orientation”, s.82.

39 Alexander Murinson, “The Strategic Depth Doctrine of Turkish Foreign Policy”, Middle Eastern Studies, Cilt 42, No.6, 2006, s.947-948.

40 Aslı Aydıntaşbaş, “Türkiye Kürtlerle Büyür”, Milliyet, 27 Kasım 2012, http://www.milliyet.com.tr/yazarlar/asliaydintasbas/turkiye-kurtlerle-buyur-1633477/ (Erişim Tarihi 29 Haziran 2017); Nazan Özcan, "Diş Siyasette Ergenlik Hülyaları”, Agos, 11 Mart 2016, http://www.agos.com.tr/tr/yazi/14647/dis-siyasette-ergenlik-hulyalari (Erişim Tarihi 29 Haziran 2017).

41 Charountaki, “Turkish Foreign Policy and the Kurdistan Regional Government”, s.192.

42 Helin Sarı Ertem, “Turkish-American Relations and Northern Iraq: Relief At Last?”, Özden Zeynep Oktav (der.), Turkey in the 21st Century: Quest for a New Policy, New York, Ashgate, 2011, s.61. 
2008'den itibaren Türkiye-IKBY ilişkileri daha çok ekonomik çıkarlar çerçevesinde konuşulmaya başlanmış, Kuzey Irak'taki PKK varlığı, Tayyip Erdoğan'ın dış politika söylemindeki merkezi yerini kaybetmiştir. Bu dönemde Türkiye-IKBY ilişkileriyle ilgili haberler daha çok petrol ve doğal gaz şirketlerinin IKBY'deki yatırımları ve Türkiye-IKBY arasındaki enerji anlaşmaları üzerinde durmuştur. ${ }^{43}$ Türkiye'nin (büyük oranda IKBY'ye giden) Irak'a ihracatı 2004 yılında 2 milyar dolardan azken, 2013'te 10 milyar doların üzerine çıkmıştır. ${ }^{44}$ IKBY'deki pek çok büyük cadde ve hükümet binasıyla Erbil Uluslararası Havaalanı'nı da Türk şirketler yapmıştır. Ayrıca IKBY'nin petrolü, 2014'ten itibaren Türkiye'den uluslararası pazarlara ulaşmaya başlamıştır. ${ }^{45}$ Özetle, Tablo 2'de de belirtildiği üzere, 2008'den itibaren gerek söylem, gerek davranış düzeyinde Türkiye Iraklı Kürtleri siyasi ve ekonomik ortağı olarak görmeye başlamış, çeşitli alanlarda yakın ilişkiler kurulmuştur.

Bu süreçte Türkiye'nin Irak'ın federal yapısını da kabullendiği gözlemlenmiştir. 2011'de Tayyip Erdoğan IKBY'yi ziyaret eden ilk Türk başbakanı olmuştur. Erdoğan, Erbil Uluslararası Havaalanı’nın açılış töreninde Mesut Barzani’ye "sevgili kardeşim” diye seslenmiş, “[b]iz, bir yandan müteahhitlerimizin, yatırımcılarımızın başarısıyla övünüyor, bir yandan da komşu bir ülkenin, kardeş Kürt halkının refahının artmasıyla seviniyoruz.” demiştir. ${ }^{46}$ IKBY başkanı Mesut Barzani 2012'de AKP kongresine konuşma yapmak üzere davet edilmiştir. Birkaç yıl önce Barzani’nin, Türk politika yapıcıları tarafından aşiret lideri olarak nitelendirildiği düşünülürse, bunun önemli bir gelişme olduğu rahatlıkla söylenebilir. Barzani bu dönemde, Türkiye'nin PKK'yla yürüttügü çözüm sürecinde de kolaylaştırıcı bir rol oynamıştır.

Türkiye-IKBY ilişkilerinin normalleştiğini gösteren bir diğer işaret, Kasım 2013'te Diyarbakır'da gerçekleşen Barzani-Erdoğan buluşmasıdır. Bu tarihi buluşmada, Türkiye ve IKBY bayrakları birlikte dalgalanmış, Erdoğan IKBY'deki Kürtlerden söz ederken ilk defa “Kürdistan” kelimesini kullanmıştır.

Türkiye'nin Kuzey Irak’a yönelik bu diş politika değişim sürecinde Tayyip Erdoğan, son sözü söyleyen temel aktör olarak karşımıza çıkmaktadır. Erdoğan’ın Iraklı Kürtlere yönelik değişen söylemi ve girişimleri süreci şekillendiren başlıca unsurlardır. Bu nedenle söz konusu politika değişikliği, kısmen Hermann ve Doeser'in tartıştı̆̆ı lider-kaynaklı değişimin bir örneği olarak değerlendirilebilir. Fakat lider-kaynaklı dış politika değişimi kavramı, bu değişikliği tamamıyla açıklayamamaktadır. Çünkü bu değişikliğin ayrıntılarını ve zamanlamasını, 2003 Irak Savaşı́nın ortaya çıkardığı bölgesel koşulları ve farklı aktörlerin katkılarını hesaba katmadan açıklamak mümkün değildir.

$\mathrm{Bu}$ çerçevede, Gustavsson tarafından geliştirilen model, 2007/2008'den itibaren Kuzey Irak politikasındaki değişikliği de açıklamakta araştırmacılara yararlı bir analitik çerçeve sunmaktadır. Daha önce belirtildiği gibi, Gustavsson’a göre dış politika değişim süreçleri, temel yapısal koşullardaki değişikliklere, siyasi liderlere ve bir kriz durumunun var olup olmadığına bakarak anlaşılabilir. ${ }^{47}$

2000’lerin başlarında Türkiye’nin karşı karşıya kaldığı çok önemli bir yapısal değişiklik, 11 Eylül 2001'de ABD'ye yapılan terör saldırılarıdır. Bu saldırılarla yeni bir uluslararası düzen ortaya çıkmış ve "terörle küresel savaş" kavramı, yeni düzenin çerçevesini oluşturmuştur. Terörün küresel bir sorun olarak tanımlanması, Türkiye ile başta ABD olmak üzere pek ülke için terörle ortak mücadele fırsatları

43 David Romano, "Iraqi Kurdistan and Turkey: Temporary Marriage?” Middle East Policy, Cilt 21, No.1, 2015 , s.91.

44 Barkey, On the KRG, the Turkish-Kurdish Peace Process, and the Future of the Kurds, s.4.

45 Soner Çağaptay, “Turkey's Kurdish Path”, Policy Notes 23, The Washington Institute for Near East Policy, 2015 , s.2.

46 “Erdoğan Erbil'de Tatlıses'i Andı!”, Milliyet, 29 Mart 2011, http://www.milliyet.com.tr/erdogan-erbil-de-tatlisesi-andi-/ siyaset/sondakikaarsiv/29.03.2011/1370657/default.htm (Erişim Tarihi 20 Mayıs 2016).

47 Gustavsson, “How Should We Study Foreign Policy Change?”, s.74. 
yaratmıştır. Fakat 11 Eylül saldırılarının Türk dış politikası açısından asıl önemli sonuçları, ABD’nin 2003 'te Irak'ı işgaliyle yaşanmaya başlamışırı. Irak Savaşı'yla ortaya çıkan yeni bölgesel dinamikler, 2000'li yılların ortalarından itibaren Türkiye'nin Kuzey Irak politikasındaki değişiklikleri tetiklemiştir.

$\mathrm{Bu}$ dinamiklerden bir tanesi, IKBY'nin Irak Savaşı sonrasında Irak'ın geri kalanına kıyasla istikrarlı bir bölge olarak dikkat çekmesidir. Çevresindeki aktörlere pek çok ekonomik firsat da sunan IKBY'deki bu gelişmeler, Türkiye'nin IKBY'ye farklı bir bakış açısı geliştirmesine olanak sağlamıştır. Kuzey Irak, büyüyen Türk ekonomisi için yatırım yapılabilecek bir alan ve ülkenin artan enerji ihtiyaçlarını karşılayabilecek alternatif bir kaynak olarak algılanmaya başlamıştır. Bu çerçevede Türkiye-IKBY arasında artan ekonomik ilişkilerin önemli bir boyutu, Kuzey Irak'taki petrol ve doğal gaz kaynakları olmuştur. Kasım 2013'te Türkiye ile IKBY arasında enerji alanında bir anlaşmaya varılmış ve Kuzey Irak petrolü Ceyhan Limanı'ndan Mayıs 2014'te hareket etmeye başlamıştır. Temmuz 2015'te Irak'tan Ceyhan Limanı'na petrol ihracatı 16 milyon varili bulmuştur. ${ }^{48}$

Türkiye’nin Kuzey Irak politikası açısından Irak Savaşının ortaya çıkardığı bir başka bölgesel dinamik de, Irak'taki belirsiz siyasi ortamın PKK'ya sunduğu yeni firsatlardır. Böylelikle PKK, 1999'da ilan ettiği tek taraflı ateşkese son vermiş ve Türkiye'ye karşı şiddet eylemlerine Haziran 2004'te tekrar başlamıştır.

AKP hükümeti aslında Türkiye’nin Kürt sorununa farklı bir bakış açısıyla göreve başlamıştır. Hükümet ilk yıllarında güçlü bir Avrupa Birliği (AB) vizyonu ortaya koymuş ve TBMM’den pek çok uyum reformu geçmiştir. Bu uyum yasaları özellikle askerin siyasetteki rolünü azaltmaya ve Kürtlere bazı kültürel haklar tanımaya yönelik değişiklikler getirmiştir. Fakat hükümetin Kürt sorununa farklı bakış açısını ortaya koyan ilk anahtar gelişme, Tayyip Erdoğan'ın Ağustos 2005'teki Diyarbakır konuşmasıdır. Burada Erdoğan, devletin geçmişte Kürt sorunuyla ilgili bazı hatalar yaptığını ifade ederek "Kürt sorunu benim sorunumdur" demiştir. ${ }^{49}$

Erdoğan'ın Diyarbakır konuşması, AKP’nin Kürt sorununun çözümüne yönelik girişimleri için önemli bir altyapı oluşturmuştur. Bu girişimlerden en önemli ikisi 2009'da başlatılan "Kürt Açılımı" ile Kürt Açılımı'nın çökmesinden sonra 2012'nin sonlarından 2015 yazına kadar süren çözüm sürecidir. 2012'nin sonlarında, PKK lideri Abdullah Öcalan, Milli İstihbarat Teşkilatı (MİT) yetkilileri ve Barış ve Demokrasi Partisi üyeleri arasında bir diyalog süreci başlamıştır. Öcalan Mart 2013'te tek taraflı ateşkes ilan etmiş ve PKK Türkiye'den çekilmeye başlamıştır.

$\mathrm{Bu}$ gelişmeler, Türkiye-IKBY arasında yakın ilişkiler kurulması süreciyle de yakından ilgilidir. 2004'te PKK’nın Türkiye'ye karşı tekrar terör eylemlerine başlaması, Türk politika yapıcıları açısından Kuzey Irak’a yönelik alternatif politikaların düşünülmesini gerekli kılmıştır. Buradaki PKK varlığı için Iraklı Kürt liderleri suçlamak yerine yakın ilişkiler geliştirip Kürt sorununun çözümü ve PKK'yla mücadelede onların desteğini almak böyle bir alternatif bakışın ürünüdür. Bu girişimin hayata geçmesinde siyasi irade olarak Tayyip Erdoğan'in tercihleri her ne kadar anahtar bir rol oynasa $\mathrm{da}$, dönemin bu bakış açısını benimseyen diğer siyasi aktörlerinin ve bürokratlarının girişimleri de bu tercihlerin hayata geçirilmesini olanaklı kılmıştır. Örneğin dönemin Dışişleri Bakanı (daha sonra Cumhurbaşkanı) Abdullah Gül, Türkiye’nin Iraklı Kürtlere yönelik alternatif bir bakış açısı geliştirmesini desteklemiş, 2005’teki bir açıklamasında "Kürt kökenli Iraklı akrabalarımızla tarih

48 “Turkey Plays 'Key Role' in Transferring Iraqi Kurdish Oil”, Hürriyet Daily News, 16 Ağustos 2015, http://www. hurriyetdailynews.com/turkey-plays-key-role-in-transferring-iraqi-kurdish-oil----.aspx?pageID $=238 \& \mathrm{nID}=87015 \& \mathrm{Ne}$ wsCatID=348 (Erişim Tarihi 20 Mayıs 2016).

49 Turan Yılmaz, “Kürt Sorunu Benim Sorunum”, Hürriyet, 13 Ağustos 2005, http://www.hurriyet.com.tr/kurt-sorunubenim-sorunum-342020 (Erişim Tarihi 4 Ekim 2017). 
boyunca nasıl bir arada yaşadıysak, yine barış ve uyum içinde yaşayacağız" demiştir..$^{50}$ Dönemin Irak özel temsilcisi (daha sonra Bağdat Büyükelçisi) Murat Özçelik, MİT Müsteşarı Emre Taner ve Türkiye'nin ilk Erbil Başkonsolosu Aydın Selcen gibi isimler de Türkiye'nin Iraklı Kürtlerle yakın ilişkiler geliştirmesinin gereğine inanarak bu düşüncenin pratiğe uygulanmasında önemli roller üstlenmişlerdir. ${ }^{51} \mathrm{Bu}$ dönemde Irak'tan askerlerini çekme sürecinde olan ABD de Türkiye'nin IKBY ile ilişkilerini düzeltmesi düşüncesini desteklemiştir. ${ }^{52}$

Erdoğan liderliğinde Türkiye'nin Iraklı Kürtlerle ilişkilerini geliştirme politikası, 2005'te MİT Müsteşarı Emre Taner'le Iraklı Kürt liderler arasında gerçekleşen gizli görüşmelerle başlamıştır. ${ }^{53}$ Fakat bu girişim hemen bir dış politika değişikliğine yol açmamıştır. Bunun en önemli nedeni, bu dönemde hükümetin ve TSK'nın Türkiye'nin Kuzey Irak politikasıyla ilgili farklı görüşlere sahip olmalarıdır. TSK'ya göre, Kuzey Irak'taki PKK varlığı, Türkiye'nin terörle mücadelesinde önemli bir boyuttur ve Kuzey Irak’a sınır ötesi askeri operasyonlar düzenlenmelidir. Hükümetse bu konuda tereddüt etmiş, Irak Kürtleriyle yakın ilişkiler geliştirmenin PKK’yla mücadelede daha yararlı bir strateji olabileceğini düşünmüştür. Bu düşüncenin birkaç nedeni vardır. Birincisi, ABD'nin Irak'ı işgaliyle Türkiye'nin Kuzey Irak'ta hareket kabiliyeti sınırlanmıştır. İkincisi, Iraklı Kürtlerle ilişkileri iyileştirmek, hükümetin hem iç politikada Kürtlerin desteğini kazanma, hem de Kürt sorununu güvenlik zemininden uzaklaştırma vizyonuyla uyumludur. Üçüncü olaraksa bazı yorumlara göre, bu dönemde hükümet Türkiye'nin bu önemli dış politika konusunda TSK'nın anahtar bir aktör olarak kalmasını istememiştir.

Hükümetin Iraklı Kürtlerle yakın ilişkiler kurma girişimine dönemin Genelkurmay Başkanı Hilmi Özkök olumlu yanıt vermiş ve Irak'taki gelişmelere paralel olarak Türkiye'nin Kuzey Irak politikasının da değişebileceğini ifade etmiştir. ${ }^{54}$ Özkök bu cümlesiyle 2005 'te IKBY’ye özerk Kürt bölgesi statüsü veren yeni Irak Anayasasına işaret etmiştir. Fakat 2006'da Genelkurmay Başkanı olan Yaşar Büyükanıt' in Türkiye'nin Kuzey Irak'la olan ilişkilerine çok daha şahin bir bakışı bulunmaktadır. Büyükanıt, Türkiye'nin yalnızca Iraklı Kürt liderlerle diyalog içerisinde olmasına karşı olmamış, aynı zamanda Kuzey Irak’a askeri bir operasyonu da şiddetle savunmuştur. ${ }^{55}$ Şubat 2007 'de Başbakan Erdoğan Iraklı Kürt liderlerle görüşeceğini açıkladığında Büyükanıt bu girişime MGK bünyesinde engel olmak için gayret göstermiştir. ${ }^{56}$ Fakat bu ylllar Türkiye'de asker-sivil dengesinin $A B$ uyum süreci çerçevesinde değişmeye başladığı ve sivil politikacıların ağırlık kazandığı bir dönemdir. Örneğin Büyükanıt Şubat 2007'de PKK'ya destekleri nedeniyle Kuzey Irak'taki Kürt gruplarla görüşmeyeceğini ifade ettiğinde Erdoğan, Türkiye’nin Iraklı Kürtlerle görüşmeden hiçbir çözüme ulaşamayacağını belirtmiştir. ${ }^{57} 2007$ Cumhurbaşkanlığı seçimlerinin ilk tur oylamasının olduğu 27 Nisan 2007'de güçlü

50 “MİT, Barzani ile Görüştü”, Radikal, 15 Kasım 2005, http://www.radikal.com.tr/yorum/mit-barzani-ilegorustu-764200/ (Erişim Tarihi 30 Haziran 2017).

51 Bkz. Bill Park, Turkey-Kurdish Regional Government Relations after the U.S. Withdrawal from Iraq: Putting the Kurds on the Map? Strategic Studies Institute and U.S. Army War College Press, Mart 2014, s.8-9.

52 David L. Phillips, Confidence Building between Turks and Iraqi Kurds, The Atlantic Council of the United States, June 2009, s.i.

53 Sarı Ertem, “Turkish-American Relations and Northern Iraq”, s.60.

54 “Irak Politikası Değişebilir”, Radikal, 24 Mart 2005, http://www.radikal.com.tr/turkiye/irak-politikasidegisebilir-741821/ (Erişim Tarihi 15 Nisan 2016).

55 Mustafa Kibaroğlu, “Turkey’s Foreign Policy Toward Northern Iraq Still Undecided”, Terrorism Monitor, Cilt 5, No.13, 2007, http://www.jamestown.org/single/?no_cache=1\&tx_ttnews\%5Btt_news\%5D=4287\#.Vc2_52AxFXg (Erişim Tarihi 16 Nisan 2016).

56 Gencer Özcan, The Changing Role of Turkey's Military in Turkish Foreign Policy Making, UNISCI discussion papers, No.23, 2010, s.39.

57 Namık Durukan, “AKP, Barzani ile Temasta”, Milliyet, 11 Eylül 2007. http://www.milliyet.com.tr/2007/09/11/siyaset/ siy02.html (Erişim Tarihi 21 Mayıs 2016). 
bir laiklik vurgusuyla Genelkurmay Başkanlığı web sayfasına konan bir metinle başlayan ve daha sonra e-muhtıra olarak adlandırılan süreçten sonra bu denge iyice sivil tarafa doğru kaymıştır. Yapılan erken genel seçimler sonucu AKP yeniden tek parti hükümeti kurmuş ve sonrasındaki cumhurbaşkanlığı seçimlerinde de TSK'nın karşı olduğu Abdullah Gül Türkiye'nin Cumhurbaşkanı seçilmiştir. ${ }^{58}$

Asker-sivil ilişkilerindeki bu değişim süreci, Türkiye’nin Kuzey Irak politikasında bazı iniş çıkışlara neden olmuştur. Hükümetin ve TSK'nın farklı bakış açıları nedeniyle Türkiye'nin Kuzey Irak politikası 2005-2007 arası dönemde belirsizlikler yaşamıştır. Örneğin, Şubat 2007'de Türkiye'nin IKBY ile ilişkilerini geliştirmek için adımların atılabileceğini söyleyen Tayyip Erdoğan, Haziran 2007'de IKBY başkanı Mesut Barzani için Türkiye'nin aşiret liderleriyle görüşmeyeceğini söylemiştir.

Bununla birlikte, 2000'li yılların başlarından itibaren AB uyum reformları, E-muhtıra çerçevesinde yaşanan gelişmeler ve 2007/2008 döneminde TSK'ya yönelik darbe iddiaları ve soruşturmaları, TSK'nın politik bir aktör olarak geri planda kalmasına yol açmış ve Tayyip Erdoğan'ın Kuzey Irak’a yönelik politika değişimi konusundaki tercihlerinin hayata geçmesini kolaylaştırmıştır. Hatta 24 Nisan 2008 tarihinde MGK, hükümetin Kürtler de dâhil Irak'taki bütün gruplarla iletişim kurmasına olanak sağlayan bir öneriyi onaylamıştır. ${ }^{59}$ Böylelikle IKBY ile yakın ilişkilerin yolu açılmıştır. ${ }^{60}$

\section{Sonuç}

Bu çalışmada 1990'ların başında ve 2007/2008'den itibaren Türkiye'nin Kuzey Irak’a yönelik dış politika değişim süreçleri incelenmiş, söz konusu süreçlerde liderin rolünün kuramsal ve sistematik bir şekilde ortaya konmasına özen gösterilmiştir. Dış politikada değişim literatüründe, liderlerin değişim süreçlerindeki rolüne şimdiye kadar yeterince önem verilmemiştir. Bu çerçevede araştırma hem ulusal, hem de uluslararası literatürdeki boşluğun doldurulmasına katkıda bulunmayı amaçlamaktadır.

Özal ve Erdoğan dönemlerinde Türkiye'nin Kuzey Irak’a yönelik dış politika değişim süreçleri, Gustavsson ve Doeser'in diş politikada değişim modelleri çerçevesinde açılanabilmektedir. Buna göre, her iki dönemdeki dış politika değişikliğinin de tam anlamıyla lider-kaynaklı olarak kavramsallaştırılamayacağı görülmüştür. Gerek Özal, gerekse Erdoğan söz konusu politika değişikliklerinin başlatılmasında ve sonuçlanmasında başlıca aktör olsalar da, bu değişim süreçlerinin yapısal/çevresel faktörlerden bağımsız olarak açıklanamayacağı gözlemlenmiştir. Bununla birlikte, iki dönemin dinamiklerinin birbiriyle aynı olduğunu söylemek de yanıltıcı olacaktır.

Öncelikle, dış politika değişim sürecinde liderin rolü konusunda, iki dönem birbirinden farklıdır. 1980'lerde ve 1990'ların başında, Turgut Özal'ı tek ve başlıca vizyoner lider olarak görmek mümkündür. Özal 1983'te başbakanlık görevine belli bir dış politika vizyonuyla gelmiştir ve görevi boyunca geliştirdiği politikalarda bunun etkilerini gözlemlemek mümkündür. Her ne kadar Tayyip Erdoğan için de büyük oranda bunları söyleyebilsek de, Erdoğan dönemi dış politika vizyonu açısından Ahmet Davutoğlu’nun rolünü yadsıyamayız. Kuzey Irak politika değişikliği açısından ise Erdoğan başlıca aktör olarak karşımıza çıksa da, bu politikanın genel çerçevesi, Davutoğlu'nun dış

58 Yaprak Gürsoy, “The Impact of EU-Driven Reforms on the Political Autonomy of the Turkish Military”, South European Society and Politics, Cilt 16, No.2, 2011, s.296.

59 Sarı Ertem, “Turkish-American Relations and Northern Iraq", s.60.

60 Türkiye’nin IKBY politikası Erdoğan'ın özellikle Mesut Barzani ve Neçirvan Barzani ile iletişimi etrafında şekillenmekte ve tüm Iraklı Kürt grupları aynı şekilde kapsamamaktadır. Bu, Özal'ın Mesut Barzani ve Celal Talabani'yle eş zamanlı iletişim kanalları açmasıyla karşılaştıııldığında farklı bir durumdur. 
politika vizyonuna ve stratejik derinlik doktrinine referans vermeden açıllanamayacağı gibi; Abdullah Gül, Murat Özçelik, Emre Taner ve Aydın Selcen gibi isimlerin katkılarını da vurgulamak gerekir.

İkinci olarak, dış politika değişim süreçlerinin dinamiklerine de bakılmalıdır. Burada Türkiye'nin Kuzey Irak'la ilgili güvenlik endişesinin Erdoğan döneminin en başından beri karar verme süreçlerinin bir parçası olduğu vurgulanabilir. Çünkü bu endişe $1991 \mathrm{Körfez} \mathrm{Savaşı} \mathrm{yla} \mathrm{ortaya} \mathrm{çıkmış,}$ Irak Savaşı yla bambaşka dinamikler kazanmıştır. Özal dönemi içinse bu geçerli değildir. Her ne kadar Türk politika yapıcıları 1960'lardan itibaren Kuzey Irak'taki Kürt hareketinden rahatsız olsalar da PKK’nın 1980'lerde eylemlerine başlamasına ve hatta 1991 Körfez Savaşı'na kadar Kuzey Irak konusu Türkiye'nin öncelikli ulusal güvenlik sorunu değildir. Bu farklılık iki liderin konuyu algılayışlarını ve verdikleri tepkiyi etkilemiştir. Erdoğan için Kuzey Irak sorunu uzun yıllardır çeşitli girişimlere rağmen çözülememiş bir sorundur. Dış politika değişim sürecinin dinamikleri açısından başka bir farklılık, Gustavsson'ın vurguladığı "kriz" durumuyla ilgilidir. Gustavsson, kriz durumlarının, yarattığı aciliyet duygusu nedeniyle, dış politika değişim süreçlerinde kolaylaştırıcı bir rol oynadığını söylemiştir. Türkiye'de hem Turgut Özal, hem Tayyip Erdoğan Kuzey Irak politikaları açısından kriz durumlarıyla karşı karşıya kalmışlardır. Özal dönemindeki aciliyet, 1991 Körfez Savaşı sonunda yaşanan sığınmacı krizidir. Erdoğan açısından da PKK'nın 2004'te tek taraflı ateşkesine son vermesi bir kriz olarak değerlendirilebilir. Fakat sığınmacı krizi çok daha acil sonuçları olan ve Türkiye'yi bir an önce yanıt üretmeye zorlayan bir gelişmedir. Erdoğan içinse zamana yayılan bir kriz durumundan söz etmek daha uygundur. Belki biraz da bu nedenle Özal’ın 1990'ların başında acil müdahale gerektiren sığınmacı krizi karşısındaki bireysel girişimleri ön plana çıkmıştır.

Son olarak, Türkiye'nin Kuzey Irak politikası değişim süreçlerini, değişimin doğası açısından da karşılaştırmak mümkündür. 1991 Körfez Savaşı sonunda her ne kadar Turgut Özal Iraklı Kürtlerle yakın ilişkiler geliştirmeye yönelik bir politika sürdürse de, bu ilişkiler hep Kuzey Irak'taki PKK varlığı çevresinde tanımlanmıştır. Diğer bir deyişle, Iraklı Kürtlerle PKK’ya karşı bir güvenlik işbirliği oluşturulmaya çalışılmıştır. Erdoğan döneminde, konunun güvenlik boyutu tamamıyla ortadan kalkmasa da, 2007/2008 yıllarından itibaren güvenlik, Türkiye’nin Kuzey Irak’a yönelik tek bakış açısı olmaktan çıkmıştır. Türkiye-IKBY ilişkilerinde önemli bir ekonomik boyut oluşmuş, iki aktör arasındaki yatırımlar, ticari ilişkiler ve enerji anlaşmaları ön plana çıkmıştır. 